Original article

\title{
mtDNA analysis of the human remains buried in the sarcophagus of Federico II
}

\author{
Alfredo Salerno ${ }^{\mathrm{a}}$, Giampietro Lago ${ }^{\mathrm{c}}$, Andrea Berti ${ }^{\mathrm{c}}$, Francesco Calì ${ }^{\mathrm{d}}$, Mario Mirisola ${ }^{\mathrm{b}}$, \\ Patrizia Carta ${ }^{\mathrm{a}}$, Carmen Ferro ${ }^{\mathrm{a}}$, Valentino Romano ${ }^{\mathrm{b}, \mathrm{d}, *}$ \\ ${ }^{a}$ Sezione di Patologia Generale, Corso Tukory 211, Palermo, Italy \\ b Sezione di Biologia e Genetica, Dipartimento di Biopatologia e Metodologie Biomediche, \\ Facoltà di Medicina e Chirurgia, Università degli Studi di Palermo, Via Divisi 83, 90133 Palermo, Italy \\ c Sezione di Biologia-RIS di Roma, Raggruppamento Carabinieri Investigazioni Scientifiche, Viale Tor di Quinto 119, Rome, Italy \\ d Laboratorio di Genetica Molecolare, Istituto OASI (IRCCS), Via Conte Ruggero 73, Troina, EN, Italy
}

Received 24 May 2005; accepted 2 July 2005

\begin{abstract}
The sarcophagus containing the remains of Federico II, located in the Cathedral of Palermo (Sicily, Italy), was opened on 1998 to perform a multidisciplinary survey [1]. Next to the remains of Federico II and in close contact with them were laying two other skeletons belonging, according to historical records, to Pietro II di Aragona and to an anonymous person ("The Third Individual"), probably a woman. The bones appeared severely deteriorated. Chemical analysis performed on bone samples excluded that the bodies underwent some kind of embalming process. The analysis of mtDNA from bone samples taken from the three skeletons was successful in only one of the two labs involved. The HVR1-mtDNA sequence (region: from nt 16,035 to nt 16,395), obtained from the bone samples of Federico II and "The Third Individual" appear identical but bear double peaks at the same nucleotide positions, suggesting mixing (i.e. contamination) of different mtDNA types. The HVR1 sequence obtained from the bone sample of Pietro II di Aragona does not present double peaks and differ from the Cambridge Reference Sequence (CRS) at six nucleotide positions. Cloning experiment of the Federico II amplicon demonstrated that the mixed mtDNA types are only two: one identical to CRS, the other identical to the sequence of Pietro II di Aragona. A reconstruction of these data are proposed in the Discussion. Due to the problematic context in which this study was carried out (mixed and deteriorated biological material, failure to replicate results in two different labs), our results and reconstruction can only be offered on a tentative basis. It is hoped that the data presented in this study will reveal useful, for future comparison, if further molecular genetics research will be carried out on the royal dynasties that ruled Sicily in the early centuries of the past millennium.
\end{abstract}

(C) 2005 Elsevier SAS. All rights reserved.

Keywords: Federico II; Pietro II di Aragona; mtDNA; Ancient DNA; Sicily

\section{Research aims}

The aim of this study was to define the mitochondrial DNA sequence types of the three skeletons buried in the sarcophagus of Federico II. This information could be potentially relevant in light of the historically disputed identity of the three individuals to whom the buried remains belong.

\footnotetext{
* Corresponding author. Tel.: +39091655 4602; fax: +39 0916554624

E-mail address: vromano@unipa.it (V. Romano).
}

\section{Introduction}

Federico II was one of the leading and most fascinating figures of the medieval Europe. He deserved citations by Dante Alighieri in the Divine Comedy, who defined him "...the last Emperor of Romans..." Not only, he was the 16th Emperor of the Holy Roman Empire, was he also crowned king of Germany, king of Sicily and king of Jerusalem. Born in Iesi (near the city of Ancona, chief town of the Marche region) on 1194 from Enrico VI (Hoenstaufen) and from Costanza d'Altavilla (Norman), he spent many years of his life in Palermo (chief town of the Sicily region). Being one of the earliest leading 
actors of the Italian Renaissance, he founded the University of Naples, reorganized the Medical School of Salerno and opened the doors of his Court to poets, philosophers, doctors, and scientists. As an enlightened monarch, his public action was informed to a strong sense of political universalism. His political views were handed down to posterity through his Constitutiones Melphitanae. Though most of the literary tradition has praised the virtues of the "Stupor mundi", there are also some critical views about his figure [2].

After death (Castel Fiorentino in the Apulia region on 1250), his body was transported on a long ground-trip to Palermo where he was buried inside a porphyritic sarcophagus located in the Cathedral's Cemetery of Kings on 1251. According to the literary sources, nearly 90 years later, Guglielmo Duca di Atene and Pietro II di Aragona, two brothers' distant descendants of Federico II (see Fig. 1), were buried in the same sarcophagus on 1338 and 1342, respectively.

On 1781 the sarcophagus was re-opened for the third time for the will of Ferdinando di Borbone, king of the "Two Sicilies". The project, led by the architect Ferdinando Fuga, aimed at restoring the Cathedral of Palermo and, in that context, at moving the royal graves to a new location inside the Cathedral, actually the place where they are still located today. The survey of 1781 confirmed the presence of three bodies but unexpectedly revealed that one of the three bodies seemed to belong to a woman (named "The Third Individual"), whereas the body of Guglielmo, Duca di Atene was apparently missing [3,4]. Daniele's report thus raised two important questions: (i) who is the woman (recently renamed "The Third Individual")? and (ii) where was the body of Guglielmo buried? recent study [5], has provided strong evidences, based on anatomical examination, that the sex of the so-called "Third Individual" could indeed be female. The detailed description and illustrations re-

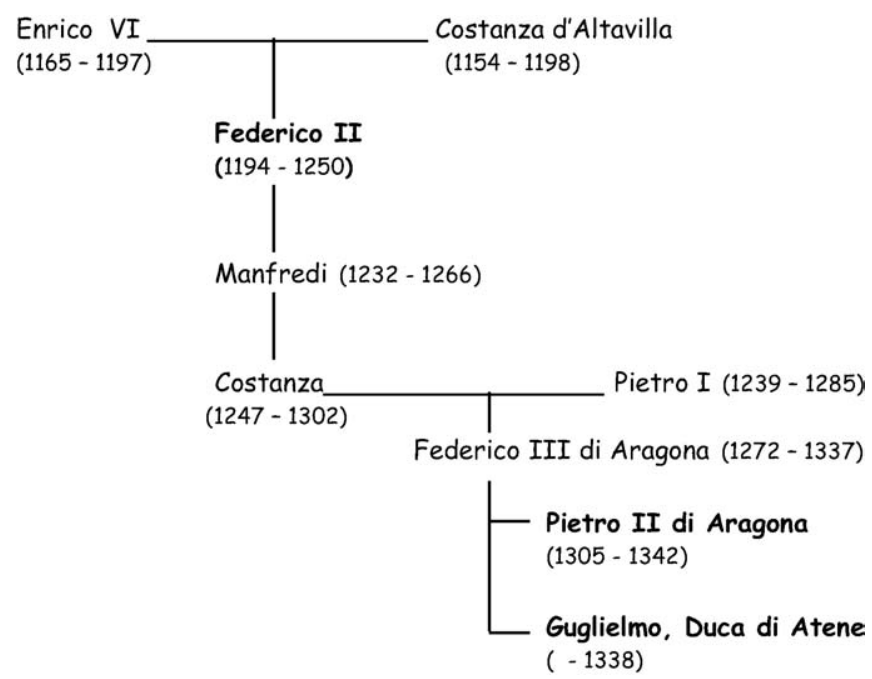

Fig. 1. Partial reconstruction of the genealogical tree linking Federico II to Guglielmo Duke of Athens and Pietro II di Aragona. They were all buried inside the sarcophagous, now located in the Cathedral fof Palermo, on 1251, 1338 and 1342, respectively. According to the report of Daniele. when the sarcophagous was reopened on 1781, the remains of Guglielmo were missing, whereas another body, named "The Third Individual" and probably belonging to a woman was found. turned to us by Daniele [3] witnesses of the good state of preservation of the three bodies at least until 1781. After that date, the sarcophagus while staying in the Marble's room remained open until 1802 (i.e. 20 years!) thus exposing its content to natural deterioration, tampering, thefts and vandalism.

To celebrate the eighth century (1194-1994) since the birth of Federico II the "Assessorato Beni Culturali e Ambientali e della Pubblica Istruzione" of the Sicilian Region [1] in collaboration with the Archidiocesan Curia of Palermo has launched a multidisciplinary project, started on 1994 and ended on 1999, whose aim was to re-open the sarcophagus and to perform a new scientifically-based survey on its content. The results of the many studies performed within the framework of this project have been recently published [1].

As part of the 1994 project, bone samples from the three skeletons were taken for DNA and chemical analyses. The interest on these studies concerned the possibility of addressing, within the limitations generally imposed by ancient DNA studies, questions concerning the real identity of the three bodies buried in the sarcophagus. In the present study, we report the results of: (i) a chemical analysis aiming at verifying whether the bodies underwent some kind of embalming process and (ii) an analysis of the HVR1 region of mitochondrial DNA from the three skeletons buried in the sarcophagus of Federico II.

\section{Material and methodologies}

\subsection{Collection of bone samples and labs involved}

The procedures followed for the opening of the sarcophagus and for samples collection are described in detail on a separate publication [6]. Four bone samples taken from the three skeletons were used in this study and they will be termed throughout this paper as follows: (i) S1a (a fragment from the malleolus of Federico II), S1b (a fragment from the right distal tibia-perone of Federico II), S2 (a fragment from a vertebra of "The Third Individual") and S3 (a fragment from the right distal humerus of Pietro II di Aragona). Three of these bone fragments are shown in Fig. 2 where they are identified by numbers: 148 (S1b), 149 (S2), 150 (S3). Bone samples taken from Federico II (S1a and b) and Pietro II di Aragona (S3) appeared badly preserved and presented a brownish color. Bone samples S2 and $\mathrm{S} 3$ were each cut in two pieces and further processed (DNA isolation) in lab A1 and lab C. DNA from bone samples $\mathrm{S} 1 \mathrm{a}$ and $\mathrm{S} 1 \mathrm{~b}$ were also isolated in labs $\mathrm{A} 1$ and $\mathrm{C}$, respectively. mtDNA analysis was performed in lab B for S1a, S2 and S3 bone samples, and in lab C for S1b, S2 ad S3. Cloning of the S1a amplicon was performed in lab A2.

Chemical analysis was performed in lab C.

\subsection{Chemical analysis of bone sample S1b (lab C)}

Inductively coupled plasma mass spectrometry (ICP-MS) has been employed to determine the elemental profile of a bone sample from Federico II (S1b). The measurements have been performed on a Hewlett Packard 4500 Series instrument. Ex- 


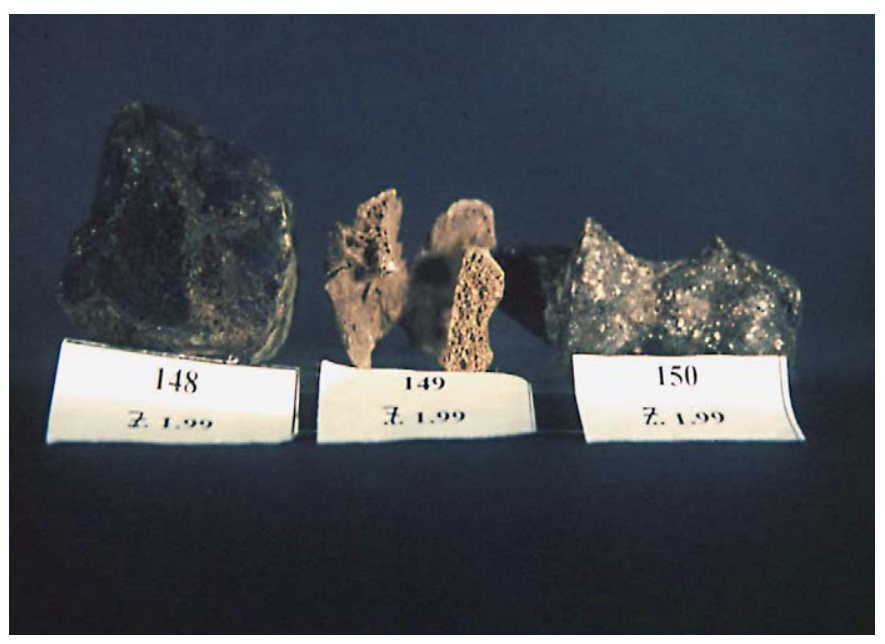

Fig. 2. Photograph of three bone fragments isolated from the skeletons attributed to Federico II, The Third Individual and Pietro II di Aragona used for mtDNA analysis. $148=$ tibia-perone from Federico II, $149=$ vertebra of The Third Individual, $150=$ humerus from Pietro II di Aragona. In the text these fragments are named as S1b (148), S2 (149), S3 (150). A fourth fragment from the malleolus of Federico II (S1a) also used for mtDNA analysis is not shown (Reproduced from RSABCAPI 2002, page 86 [1]).

ternal calibration standards were prepared in $1 \%$ nitric acid from a commercial multielement stock (Merck). Table 1 shows operating conditions employed in mass spectrometry analysis. The following elements were determined: $\mathrm{Li}, \mathrm{Be}, \mathrm{B}, \mathrm{Mg}, \mathrm{Al}$, $\mathrm{Si}, \mathrm{K}, \mathrm{Ca}, \mathrm{Sc}, \mathrm{Ti}, \mathrm{V}, \mathrm{Cr}, \mathrm{Mn}, \mathrm{Fe}, \mathrm{Co}, \mathrm{Ni}, \mathrm{Cu}, \mathrm{Zn}, \mathrm{Ga}, \mathrm{As}, \mathrm{Se}$, $\mathrm{Br}, \mathrm{Rb}, \mathrm{Sr}, \mathrm{Y}, \mathrm{Zr}, \mathrm{Ag}, \mathrm{Sn}, \mathrm{Sb}, \mathrm{Ba}, \mathrm{Cs}, \mathrm{La}, \mathrm{Ce}, \mathrm{Au}, \mathrm{Hg}, \mathrm{Tl}, \mathrm{Pb}$, $\mathrm{Bi}$ and $\mathrm{U}$. A bone sample of the same age as those of interest for the present study was used as reference.

\subsection{DNA isolation}

In all labs involved, DNA isolation from peripheral blood drawn from lab workers was performed according to standard procedures. For isolation of ancient DNA, two different protocols were used in labs A1 and C, here described, respectively, as Procedure numbers 1 and 2. Procedure 1 (Bone samples S1a, S2 and S3 analyzed in lab A1). Each bone fragment taken from the three skeletons was chilled in liquid nitrogen and crushed. Nearly $4 \mathrm{~g}$ of powder were usually obtained from each fragment. One hundred milligrams aliquots of the powder were dispensed in four different test tubes each containing $1 \mathrm{ml}$ of $0.5 \mathrm{M}$ EDTA pH 8.0. This suspension was incubated overnight at $37^{\circ} \mathrm{C}$. Tubes were then spun for $10 \mathrm{~min}$ on a bench centrifuge at $12,000 \mathrm{rpm}$ at room temperature, the supernatant was discarded. The four pellets were washed once with sterile

Table 1

Operating conditions used for ICP-MS

\begin{tabular}{ll}
\hline RF power & $1350 \mathrm{~W}$ \\
Plasma Ar flow & $14.5 \mathrm{l} / \mathrm{min}$ \\
Nebulizer Ar flow & $1.21 / \mathrm{min}$ \\
Dwell time & $50 \mathrm{~ms}$ \\
Readings per replicate & 25 \\
Number of replicates & 5 \\
Points per spectral peak & 1 \\
\hline
\end{tabular}

water to remove EDTA traces. While washing, the four pellets were pooled in one tube. After centrifugation this new spn was also discarded. The resulting pellet was resuspended in $1,294 \mu \mathrm{l}$ of lysis buffer $(1,200 \mu \mathrm{l}$ of $0.2 \mathrm{M}$ Sodium acetate $\mathrm{pH} 7.0+30 \mu \mathrm{l} 10 \%$ SDS $+24 \mu \mathrm{l} 0.5 \mathrm{M}$ EDTA $+40 \mu \mathrm{l}$ of $10 \mathrm{mg} / \mathrm{ml}$ Proteinase K). This suspension was incubated for 3 hours at $56{ }^{\circ} \mathrm{C}$. After incubation, $700 \mu \mathrm{l}$ of a solution containing $7 \mathrm{M}$ Guanidine chloride, resuspended in $25 \mathrm{mM}$ maleic acid ( $\mathrm{pH} \mathrm{6),} \mathrm{were} \mathrm{added} \mathrm{to} \mathrm{the} \mathrm{suspension.} \mathrm{This} \mathrm{new} \mathrm{suspen-}$ sion was incubated for $30 \mathrm{~min}$ at $56{ }^{\circ} \mathrm{C}$. The suspension was filtered through SPIN-X Costar columns (cellulose acetate filter pores were 0.45 millimicron, Corning, NY, USA) by spinning for $2 \mathrm{~min}$ in microfuge $12,000 \mathrm{rpm}$. The eluate was collected in $2 \mathrm{ml}$ tubes. The eluate $(2 \mathrm{ml})$ was mixed with $40 \mu \mathrm{l}$ of a suspension containing 10\% diatomaceous earth (SIGMA Chemicals St. Louis, USA, cat. \# D-5384) in distilled water and incubated for $10 \mathrm{~min}$ at room temperature. After incubation this mixture was loaded on a new SPIN-X Costar column (DNA is now bound to the resin). The column was washed three times with washing buffer $(2 \mathrm{ml} \mathrm{NaCl} 5 \mathrm{M}, 1 \mathrm{ml}$ Tris$\mathrm{HCl} 1 \mathrm{M}, 0.5 \mathrm{ml}$ EDTA $0.5 \mathrm{M}, 25 \mathrm{ml}$ ETOH were diluted to a final volume of $50 \mathrm{ml}$ with bidistilled water), once with $100 \%$ ethanol and once with $70 \%$ ethanol. The column was then baked at $56{ }^{\circ} \mathrm{C}$ for $5 \mathrm{~min}$ and DNA was eluted with $50 \mu \mathrm{l}$ bidistilled water at $70{ }^{\circ} \mathrm{C}$. Blank samples (without DNA) treated with the above procedure were also used. DNA isolation from peripheral blood drawn from lab workers was performed according to standard procedures. Procedure 2 (Bone samples $\mathrm{S} 1 \mathrm{~b}, \mathrm{~S} 2$ and S3 analyzed in lab C). Each bone fragment has been cleaned off with a scalpel blade. Bones were not washed after recovery to prevent absorption of modern DNA. Each bone surface was brushed and irradiated (1 h under UV light). DNA was extracted from powdered bone by means of a silicabase protocol (modified from Krings et al. [7]). The extractions were done with $1 \mathrm{~g}$ powdered bone. The powder was weighted on a disposable weighing boat and placed in a labeled, sterile $50-\mathrm{ml}$ polycarbonate tube with a screw cap. The powder was washed two or three times by centrifugation with $10-15 \mathrm{ml}$ of $0.5 \mathrm{M}$ EDTA solution $\mathrm{pH} 8-8.5$ to remove the soluble brown impurities. After these washing steps, $10 \mathrm{ml}$ of lysis buffer (0.5 M EDTA, pH 8-8.5, $200 \mu \mathrm{g} / \mathrm{ml}$ proteinase $\mathrm{K}$, and $0.5 \%$ $\mathrm{N}$-Iauroylsarcosine) were added to each sample tube. The tubes were incubated at $37^{\circ} \mathrm{C}$ overnight and kept shaking to maintain the bone powder in suspension. Solid matter remaining in the lysis suspension after the incubation step was subsequently removed by centrifugation during the phenol/chloroform extraction steps. The latter extractions were performed as follows: (i) one extraction with an equal volume of phenol (freshly opened water-saturated phenol, glass distilled grade- equilibrated with $20 \mathrm{mM}$ Tris-HCI, pH 7.5). The aqueous phase remained at the bottom (provided the lysis buffer contained $0.5 \mathrm{M}$ EDTA), and the top phenol layer was discarded; (ii) two extractions with an equal volume of phenol/chloroform (1:1). The aqueous phase was desalted and concentrated at room temperature using Centricon-30 microconcentrators (Amicon, Danvers, Mass.) in a benchtop or floorstanding centrifuge according to the manufacturer's advice. As the volume 
of the microconcentrators is only $2 \mathrm{ml}$, several centrifugation steps were required to concentrate all the aqueous solution. Finally, the retentate was washed at least twice with $2 \mathrm{ml}$ of sterile water. The resulting water solution is likely to contain the following substances: DNA isolated from both the original bone and from microorganisms attached to the bones, carbohydrates, some protein, and impurities like humic acids. Blank samples (without DNA) treated with the above procedure were also used. Aliquots $(5-10 \mu \mathrm{l})$ of this solution was electrophoresed through $1 \%$ agarose gels with DNA size markers, and the gels was then stained with ethidium bromide to visualize the DNA under UV light.

\subsection{Analysis of mtDNA (labs $B$ and $C$ )}

The HVR1 segment of the D-Loop region of mtDNA was amplified by Polymerase Chain Reaction (PCR) using the following primers: (np 15409) 5'-CCCTTACTACACAAT CAAAG-3' and (np 16543) 5'-CGTGTGGGCTATTTAGGC3'. Polymerase Chain Reaction (PCR) was performed in $50 \mu \mathrm{l}$ containing: $50 \mathrm{ng}$ of genomic DNA; $1 \mathrm{U}$ TaqGold DNA-polymerase (Applera, USA); $5 \mu$ reaction buffer $10 \times(20 \mathrm{mM}$ Tris-HCl pH 8, $100 \mathrm{mM} \mathrm{KCl,} 0.1 \mathrm{mM}$ EDTA, $1 \mathrm{mM}$ DTT, $50 \%$ glycerol, $0.5 \%$ Tween $20,0.5 \%$ Nonidet P40) $1.5 \mathrm{mM}$ $\mathrm{MgCl}_{2} 0.2 \mathrm{mM}$ of each dNTP $0.2 \mu$ moles of each primer. PCR cycling conditions were the same as previously described: $96{ }^{\circ} \mathrm{C}$ for $1 \mathrm{~min}, 50{ }^{\circ} \mathrm{C}$ for $1 \mathrm{~min}, 72^{\circ} \mathrm{C}$ for $1 \mathrm{~min} 30 \mathrm{~s}$ for 30 cycles. The following primers were used to sequence both strands of DNA: (F15978) 5'-CACCATTAGCACC CAAAGCT-3' and (R16543) 5'-CGTGTGGGCTATTTAGGC3', using ABI PRISM BigDye Terminator Cycle Sequencing Ready Reaction kit (PE, Applied Biosystems, Milano, Italy). Aliquots $(5-10 \mu \mathrm{l})$ of the PCR reactions were analyzed by electrophoresis on agarose gels stained with ethidium bromide or, alternatively, on polyacrylamide gels stained with ethydium bromide or silver stain (Bio-Rad Silver Stain, Bio-Rad, Richmond, Cal.). Ethydium bromide stained gels were irradiated with UV light to visualize DNA fragments. Special care was taken to handle PCR products to prevent carry-over contamination. In particular, negative controls, without DNA, containing the same components used for the various case PCR reactions were always included. Like other workers, we find that ancient DNA extracts contain a powerful PCR inhibitor. In most cases inhibition was overcome by adding bovine serum albumin to the amplification buffer and diluting the extract in order to dilute the inhibitor.

\subsection{Cloning of the S1a amplicon (lab A2)}

The amplicon obtained from mitochondrial HVR1 (range $=15409-16543$ ) segment of the S1a sample ("Federico II") was cloned in lab A2 to dissect its heterogeneity. One hundred nanograms of this amplicon were subjected to agarose gel purification with GFX PCR DNA and gel band purification kit (Amersham Pharmacia Biotech Inc., Piscataway NJ, USA). Twenty nanograms of the purified fragment have been cloned into the PCR 2.1 plasmid vector by the Topo TA cloning kit (Invitrogen, CA, USA) following the manufacturer's instructions. Isolated bacterial colonies were expanded in liquid media and their plasmid DNA was isolated as described in Sambrook and Russell [8]. DNA sequence on both strands of the DNA insert was performed in lab B following the same protocol used to sequence the amplicons (see above).

\section{Results}

\subsection{Chemical analysis}

The chemical composition was not significantly different between "case" and "control" bone samples.

\subsection{Analysis of $m t D N A$}

The following data refer only to HVR1-mtDNA sequences obtained for S1a, S2 and S3 samples in lab B. Unfortunately, mtDNA analyses performed in lab C for S1b, S2 and S3 samples were unsuccessful (no PCR product could be seen). The maximum length of HVR1 that could unambiguously be compared among all DNA samples ranged from 16,030 to 16,475 . mtDNA sequences obtained from S1a, S2 and S3 amplicons as well as mtDNA amplicons from lab workers are shown and compared to the Cambridge Reference Sequence (CRS) [9] in Table 2. As it can be seen, S1a and S2 amplicons yielded the same sequence that displays double peaks at six positions (see also electropherogram in Fig. 3), which suggest the occurrence of mixing among different mtDNA molecule types. Reassuringly, the HVR1 sequences borne by the involved workers from labs A1 and B are different from those detected in S1a, S2 and S3 mtDNAs (see Table 2), implying that they were not the source of contaminating DNA. The sequence of S3 amplicon (Pietro II di Aragona) did not yield double peaks and differ from the CRS at six nucleotide positions. Interestingly, the latter six differences are at the same nucleotide positions displaying double peaks in S1a and S2 mtDNAs (see Table 2). This finding suggested that S3 mtDNA might have been a source of contamination for both S1a and S2 mtDNAs. In order to verify this hypothesis the S1a amplicon was cloned in the PCR 2.1 vector. This approach was chosen to try to "resolve" the individual mtDNA sequence types mixed together in the amplicon from Federico II (S1a) and causing the formation of double peaks. Overall, eleven bacterial recombinant clones were analyzed and eight of them yielded (as predicted) the same HVR1 sequence detected in the S3 sequence, whereas one had a sequence identical to CRS (see Table 3). A possible and hypothetical reconstruction of these data are proposed in the following section.

\section{Discussion}

When the sarcophagus was re-opened on 1998, the body of Federico II was found nearly hidden by two other bodies and 
Table 2

Sequence analysis of the HVR1 region of mtDNA

\begin{tabular}{|c|c|c|c|c|c|c|c|c|c|c|c|c|c|c|c|c|}
\hline \multirow[b]{2}{*}{ CRS } & \multicolumn{6}{|c|}{ Variation in mtDNA HVR1 amplicons } & \multicolumn{9}{|c|}{$\begin{array}{l}\text { Other variations in mtDNA HVR1 amplicons } \\
\text { present in lab's workers }\end{array}$} & \multirow[b]{2}{*}{$\begin{array}{l}\text { Region } \\
\text { analyzed in } \\
\text { mtDNA }\end{array}$} \\
\hline & $\begin{array}{l}\mathbf{1 6 1 8 3} \\
A\end{array}$ & $\begin{array}{l}\mathbf{1 6 1 8 9} \\
T\end{array}$ & $\begin{array}{l}16248 \\
C\end{array}$ & $\begin{array}{l}\mathbf{1 6 2 4 9} \\
T\end{array}$ & $\begin{array}{l}\mathbf{1 6 3 1 1} \\
T\end{array}$ & $\begin{array}{l}\mathbf{1 6 3 2 0} \\
C\end{array}$ & $\begin{array}{l}\mathbf{1 6 0 8 6} \\
T\end{array}$ & $\begin{array}{l}16192 \\
C\end{array}$ & $\begin{array}{l}\mathbf{1 6 2 5 6} \\
C\end{array}$ & $\begin{array}{l}16261 \\
C\end{array}$ & $\begin{array}{l}\mathbf{1 6 2 7 0} \\
C\end{array}$ & $\begin{array}{l}16278 \\
C\end{array}$ & $\begin{array}{l}16298 \\
G\end{array}$ & $\begin{array}{l}\mathbf{1 6 3 1 1} \\
T\end{array}$ & $\begin{array}{l}16399 \\
A\end{array}$ & \\
\hline $\begin{array}{l}\text { S1a } \\
\text { (Federico } \\
\text { II) }\end{array}$ & $\mathbf{A}+\mathbf{C}$ & $\mathbf{T}+\mathbf{C}$ & $\mathbf{C}+\mathbf{T}$ & $\mathbf{T}+\mathbf{C}$ & $\mathbf{T}+\mathbf{C}$ & $\mathbf{C}+\mathbf{T}$ & . & . & . & . & . & & . & . & . & $\begin{array}{l}16035- \\
16475\end{array}$ \\
\hline $\begin{array}{l}\text { S2 } \\
\text { (The Third } \\
\text { Individual) }\end{array}$ & $\mathbf{A}+\mathbf{C}$ & $\mathbf{T}+\mathbf{C}$ & $\mathbf{C}+\mathbf{T}$ & $\mathbf{T}+\mathbf{C}$ & $\mathbf{T}+\mathbf{C}$ & $\mathbf{C}+\mathbf{T}$ & . & . & . & . & . & . & . & . & nd & $\begin{array}{l}16030- \\
16395\end{array}$ \\
\hline $\begin{array}{l}\mathbf{S 3} \\
\text { (Pietro II di } \\
\text { Aragona) }\end{array}$ & $\mathbf{C}$ & $\mathbf{C}$ & $T$ & $\mathbf{C}$ & $\mathbf{C}$ & $\mathbf{T}$ & nd & . & . & . & . & . & . & . & nd & $\begin{array}{l}16183- \\
16325\end{array}$ \\
\hline $\mathbf{C F}$ & $\mathbf{C}$ & $\mathbf{C}$ & . & . & . & . & . & . & . & . & . & & $\mathbf{C}$ & C & . & $\begin{array}{l}16018- \\
16450\end{array}$ \\
\hline FC & . & . & . & . & . & . & . & $\mathbf{T}$ & . & . & . & $\mathbf{T}$ & . & . & . & $\begin{array}{l}16033- \\
16489\end{array}$ \\
\hline PS & . & . & . & . & . & . & . & . & $\mathbf{T}$ & . & $\mathbf{T}$ & . & . & . & $\mathbf{G}$ & $\begin{array}{l}16035- \\
16471\end{array}$ \\
\hline
\end{tabular}

CF, FC, PS are the initials of lab workers who have isolated and analyzed DNA from bone samples. nd: not determined. Dots indicate matching with the CRS [9], as defined by the first line.

only his head was visible (see Fig. 4b). The identities of these two individuals were assigned, following the historical reconstruction (see the Introduction), to (i) Pietro II di Aragona whose remains were contained in a sac laying to the right of Federico II's body and (ii) to the so-called "Third Individual" whose bones and skull were laying to the left of the emperor. Next to Federico II's head there were also metallic fragments of both a slashed globe and the crown. His body was covered by several layers of fragmented clothes and "protected" by a red cloth whose manufacture has been dated to the XVIII century (Rosalia Varoli Piazza, unpublished data). Mass spectro-

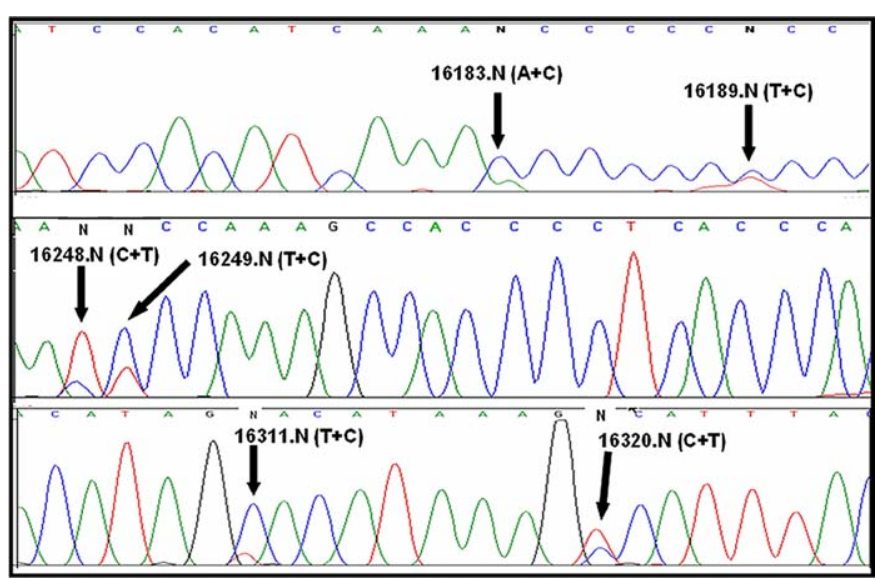

Fig. 3. Electropherogram of the sequence of the HVR1 region of the mtDNA isolated from bone sample S1a (malleolus of Federico II). Double peaks at nucleotide positions $16183,16189,16248,16249,16311,16320)$ are indicated by arrows. These double peaks have been shown to result from mixing (contamination) of two different mtDNA types (see Tables 2 and 3 and the text for explanation). metry analysis (this study) excluded the presence of unusual chemical elements or different ratios between usual elements that would have suggested that the bodies did undergo a mummification process.

The bad state of the biological material disclosed by the opening of 1998 not only reflects the effects of natural deterioration but, probably, is also the consequence of the troubled and unlucky story of the sarcophagus over 750 years since the first burial of Federico II (compare in Fig. 4 the drawing made by Daniele on 1781 with the photographs taken on 1998). On 1801 , when the sarcophagus was moved to its present location, the cover has been placed unsealed and in inverted position [10]. Temperature and humidity measurements made on 1995 and 1996 in the internal environment of the closed sarcophagus revealed that such parameters fluctuated following the variations of the external enviroment [11].

The dramatic scenario uncovered by the survey of 1998 nearly discouraged us from performing the analysis of ancient DNA. We wanted, however, carry on our study because of the unique opportunity offered by the opening of the sarcophagus.

In order to minimize biological contamination, from a source "external" to the sarcophagus, and to protect the material from further deterioration, very strict precautions were taken to open the sarcophagus and to collect bone samples (see Andaloro et al. [6] for a detailed description of these procedures). On the other hand, the contributions supplied by Cooper et al. [12]; Poinar et al. [13], and especially by Cooper and Poinar [14], have provided to us an extremely useful guide in planning and carrying out the ancient DNA study. Several negative controls introduced during the various steps of DNA analysis excluded that the contamination we saw in the HVR1 region from samples S1a (Federico II) and S2 ("The Third Individual") came from the involved workers. Our cloning experiment pro- 
Table 3

Sequence Analysis of the recombinant plasmids (pCR2.1 vector) obtained by cloning the S1a (Federico II) HVR1-mtDNA amplicon

\begin{tabular}{|c|c|c|c|c|c|c|c|}
\hline & 16183 & 16189 & 16248 & 16249 & 16311 & 16320 & \\
\hline$C R S$ & $A$ & $T$ & $C$ & $T$ & $T$ & $C$ & Analyzed region \\
\hline Clone 1 & $\mathbf{C}$ & $\mathbf{C}$ & $\mathbf{T}$ & $\mathbf{C}$ & $\mathbf{C}$ & $\mathbf{T}$ & $16020-16480$ \\
\hline Clone 2 & C & C & $\mathbf{T}$ & C & C & $\mathbf{T}$ & $16020-16480$ \\
\hline Clone 3 & $\mathbf{C}$ & $\mathbf{C}$ & $\mathbf{T}$ & $\mathbf{C}$ & $\mathbf{C}$ & $\mathbf{T}$ & $16020-16480$ \\
\hline Clone 4 & $\mathbf{C}$ & $\mathbf{C}$ & $\mathbf{T}$ & $\mathbf{C}$ & $\mathbf{C}$ & $\mathbf{T}$ & $16020-16189$ \\
\hline Clone 5 & nd & nd & $\mathbf{T}$ & $\mathbf{C}$ & $\mathbf{C}$ & $\mathbf{T}$ & $16247-16480$ \\
\hline Clone 6 & nd & nd & nd & nd & $\mathbf{C}$ & $\mathbf{T}$ & $16260-16480$ \\
\hline Clone 7 & $\mathbf{C}$ & C & $\mathbf{T}$ & $\mathbf{C}$ & $\mathbf{C}$ & $\mathbf{T}$ & $16020-16480$ \\
\hline Clone 8 & $\mathbf{C}$ & $\mathbf{C}$ & $\mathbf{T}$ & $\mathbf{C}$ & $\mathbf{C}$ & $\mathbf{T}$ & $16020-16480$ \\
\hline Clone 9 & nd & nd & nd & nd & . & . & $16250-16480$ \\
\hline Clone 10 & $\mathbf{C}$ & $\mathbf{C}$ & $\mathbf{T}$ & $\mathbf{C}$ & $\mathbf{C}$ & $\mathbf{T}$ & $16030-16480$ \\
\hline Clone 11 & $\mathbf{C}$ & $\mathbf{C}$ & $\mathbf{T}$ & $\mathbf{C}$ & $\mathbf{C}$ & $\mathbf{T}$ & $16030-16480$ \\
\hline
\end{tabular}

Only differences from the CRS [9] are shown. nd = not determined.
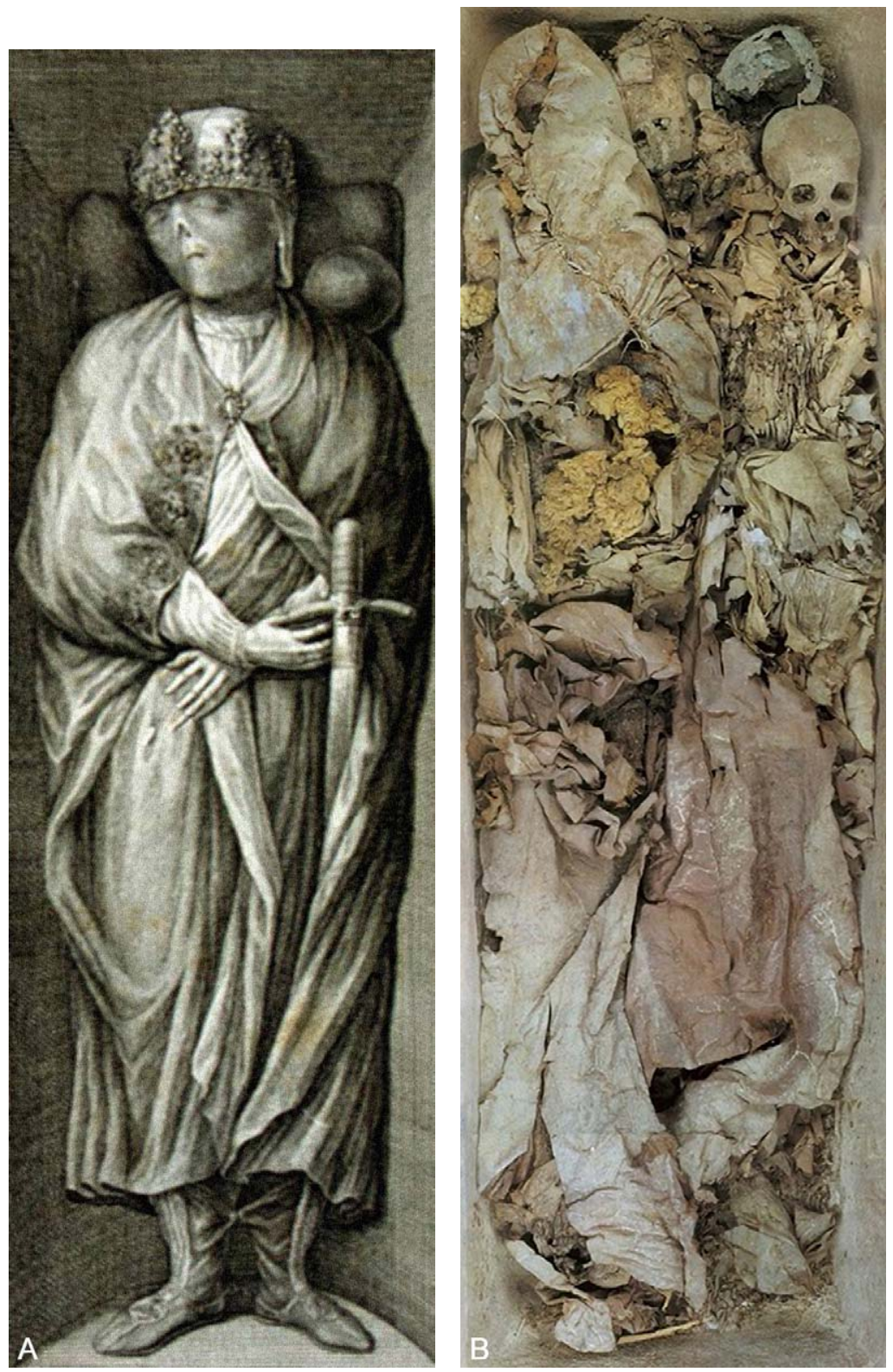

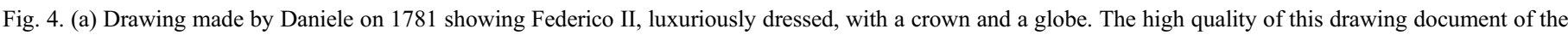
good state of preservation of his body until that date. Compare however this drawing with the pictures (b) taken after the sarcophagous was re-opened on 1998 (Reproduced from Ref.1 figures was 48 and 49 p.53 with kind permission of the Centro Regionale per la Progettazione ed il Restauro di Palermo, Italy). 
vided strong evidences that the six double peaks seen in the mtDNA sequence from S1a and S2 were due to mixing of no more than two distinct mtDNA molecule types, i.e. (i) CRS and (ii) a sequence which differ from CRS at six positions (indicated in Tables 2 and 3). This latter sequence is identical to that of Pietro II di Aragona (S3) suggesting that mtDNAs from S1a (Federico II) and S2 ("The Third Individual"), in their uncontaminated form probably a CRS type, were contaminated by the mtDNA sequence of S3 (Pietro II di Aragona). If this reconstruction is correct it would confirm that the bones of Pietro II di Aragona and of "The Third Individual" do not belong to two brothers. Clearly, the failure of lab $\mathrm{C}$ to replicate the results obtained in labs A $+\mathrm{B}$ introduces important caveats in our study which impose that both our results and interpretation be taken with strong caution. In this context it should also be pointed out that lab $\mathrm{C}$ not only used different bone fragments from the remains of both Federico II and Pietro II di Aragona than those used in lab A, also the DNA isolation protocols used by the two labs were different (see Section 3).

\section{Conclusions}

This is the first ancient DNA study on the three skeletons buried in the sarcophagus of Federico II that was carried out with the aim of exploiting the potential contribution of molecular genetics to address some aspects of historically debated issues concerning the real identity of the three bodies. Though potentially interesting in light of future studies in this field, the outcome of our mitochondrial DNA analysis could not be replicated thus introducing strong bias on the possibility of a reliable interpretations of the lab results. As experts in the field know, the short history of ancient DNA studies is punctuated by negative outcomes, which are usually caused by the bad quality and low quantity of ancient DNA that can be isolated from old specimens. In our case these limitations are reflected on the bad state of bone preservation for the three skeletons. What strengthens us in considering that our effort may not have been completely fruitless is the hope that the data presented in this study may reveal useful, for future comparison, if further molecular genetics research will be conducted on the royal dynasties who ruled Sicily in the early centuries of the past millennium.

\section{References}

[1] Regione Siciliana Assessorato Beni Culturali e Ambientali e della Pubblica Istruzione (RSABCAPI), Dipartimento dei Beni Culturali ed Ambientali e dell'Educazione Permanente, Regione Siciliana, in: Il sarcofago dell'imperatore, Officine Grafiche Riunite Press, Palermo, Italy, 2002.

[2] D. Abulafia, in: A. Lane (Ed.), Fredrick II. A Medieval Emperor, The Penguin Press, London, 1988.

[3] F. Daniele, I regali sepolcri del Duomo di Palermo riconosciuti e illustrati, Napoli, 1784 (II edition 1859).

[4] R. Gregorio, I regali sepolcri della Maggior Chiesa di Palermo illustrati, in: R. Gregorio (Ed.), Opere scelte del Can, Garofano Press, Palermo, Italy, 1845, pp. 698-712 (III Edition).

[5] M. De Maria, M. Micheli, P. Procaccianti, G. Salerno, Indagini radiografiche e rilievi medico-legali, in: Regione Siciliana Assessorato Beni Culturali e Ambientali e della Pubblica Istruzione, Dipartimento dei Beni Culturali ed Ambientali e dell'Educazione Permanente (Ed.), Il sarcofago dell'imperatore, Officine Grafiche Riunite Press, Palermo, Italy, 2002, pp. $90-94$.

[6] M. Andaloro, A. Lombardo, R. Varoli-Piazza, Ragioni e finalità, in: Regione Siciliana Assessorato Beni Culturali e Ambientali e della Pubblica Istruzione, Dipartimento dei Beni Culturali ed Ambientali e dell'Educazione Permanente (Ed.), Il sarcofago dell'imperatore, Officine Grafiche Riunite Press, Palermo, Italy, 2002, pp. 39-60.

[7] M. Krings, A. Stone, R.W. Schmitz, H. Krainitzki, M. Stoneking, S. Pääbo, Neandertal DNA sequences and the origin of modern humans, Cell 90 (1997) 19-30.

[8] J. Sambrook, D.W. Russell, Molecular Cloning a Laboratory Manual, CSHL press, CSH New York, 2001 (third ed., 1-34).

[9] S. Anderson, A.T. Bankier, B.G. Barrell, M.H.L. de Bruijn, A. R. Coulson, J. Drouin, I.C. Eperon, D.P. Nierlich, B.A. Roe, F. Sanger, P.H. Schreier, A.J.H. Smith, R. Staden, I.G. Young, Sequence and organisation of the human mitochondrial genome, Nature 290 (1981) $457-$ 464

[10] R. La Duca, Una Cattedrale per Federico, Vicende storiche del sarcofago di Federico II, in: Regione Siciliana Assessorato Beni Culturali e Ambientali e della Pubblica Istruzione, Dipartimento dei Beni Culturali ed Ambientali e dell'Educazione Permanente (Ed.), Il sarcofago dell'imperatore, Officine Grafiche Riunite Press, Palermo, Italy, 2002, pp. 303-313.

[11] C. Cacace, Progetto microclimatico di apertura del sarcofago di Federico II, in: Regione Siciliana Assessorato Beni Culturali e Ambientali e della Pubblica Istruzione, Dipartimento dei Beni Culturali ed Ambientali e dell'Educazione Permanente (Ed.), Il sarcofago dell'imperatore, Officine Grafiche Riunite Press, Palermo, Italy, 2002, pp. 228-231.

[12] A. Cooper, A. Rambaut, V. Macaulay, E. Willerselev, A.J. Hansen, C. Stringer, Human origins and ancient human DNA, Science 292 (2001) $1655-1656$.

[13] H.N. Poinar, M. Hoss, L. Bada, S. Pääbo, Amino acid racemization and the preservation of ancient DNA, Science 272 (1996) 864-866.

[14] A. Cooper, H.N. Poinar, D.N.A. Ancient, do it right or not at all, Science 289 (2000) 1139. 